\title{
KEUTAMAAN MAKAN SAHUR DENGAN TAMAR (KURMA) (KAJIAN KONTEKSTUAL HADIST ABU DAWUD)
}

\author{
Oleh: Nurul Hidayah *
}

\begin{abstract}
Abstrak
Pemahaman umat Islam dalam menafsirkan hadist terkadang masih secara tekstual, belum secara kontekstual terutama pada hadist yang mengandung majaz. Sehingga mengamalkan perintah yang terkandung dalam hadist tersebut menjadi sebuah keutamaan. Artikel ini membahas mengenai keutamaan makan sahur dengan menggunakan tamar (Kurma). Tujuan yang hendak dicapai penulis yaitu untuk mengetahui makna secara kontekstual yang terkandung dalam hadist Abu Dawud. Metode yang digunakan penulis yaitu metode kuantitatif. Adapun langkah kajian yang ditempuh oleh peneliti untuk mencapai tujuan tersebut yaitu kajian secara linguistik, tematis komprehensif, konfirmatif, realitas historis, generalisasi, dan praksis. Secara kontekstual, hasil yang diperoleh penelitiyaitu anjuran makan sahur bukan hanya untuk mencegah haus dan lapar melainkan karena pada saat sahur Allah dan para malaikat bershalawat kepada orang-orang yang melaksanakan sahur, meskipun hanya dengan seteguk air. Rasulullah menganjurkan umatnya untuk bersahur dengan makan kurma atau makanan yang manis-manis bergizi yang dapat menjadi energi ketika menjalankan ibadah puasa.
\end{abstract}

Kata Kunci: Keutamaan, Sahur, Kurma, Kontekstual, Hadist.

\section{A. PENDAHULUAN}

Hadist merupakan salah satu sumber hukum islam disamping Alquran. Meskipun Alquran dan Hadist merupakan dua hal yang berbaeda dari segi bahasa maupun istilah, akan tetapi keduanya saling melengkapi satu sama lain. Kehujjahan sebuah hadist akan kurang jika tanpa adanya Alquran. Begitu pula sebaliknya, meskipun Alquran merupakan kitab suci yang tak diragukan lagi kehujjahannya, namun akan kurang lengkap tanpa adanya hadist. Kaitannya dengan judul diatas, pokok bahasan dalam tulisan ini adalah kajian hadist. Adapun Alquran, digunakan

\footnotetext{
* Dosen Prodi PBA Fakultas Agama Islam Universitas KH. A. Wahab Hasbullah Jombang
} 


\section{Nurul Hidayah}

sebagai penguat dari kajian hadist mengenai keutamaan makan sahur dengan tamar (kurma).

Pada tulisan ini, kajian hadist bukan hanya dikaji sebatas dari aspek tekstualnya saja melainkan juga dari aspek kontekstual. Dengan melihat aspek tekstual dan kontekstual, pesan yang terkandung di dalam sebuah hadist akan dapat mudah dipahami, baik dikalangan awam maupun terpelajar. Sehingga dalam mengamalkan apa yang terkandung dalam hadist yang mengandung majaz, pembaca tidak hanya sebatas memahami secara tekstual. Hal ini dikarenakan hadist yang mengandung majaz tidak dapat dipahami secara apa adanya, namun membutuhkan penafsiran yang lebih lanjut.

Berkaitan dengan hadist yang mengandung majaz, dalam tulisan ini akan dikaji mengenai hadist tentang “Keutamaan Makan Sahur dengan Tamar (Kurma) (Kajian Hadist Abu Dawud)". Hadist yang menjadi obyek kajian dalam penelitian ini adalah hadis yang diriwayatkan oleh Abu Dawud. Kitab hadistnya yang terkenal adalah Sunan Abu Dawud. Kitab tersebut merupakan salah satu kitab hadist yang dijadikan sebagai hujjatul islamoleh para ulama fikih dalam pengambilan hukum. Imam Abu Dawud adalah salah satu ulama hadist yang paling banyak meriwayatkan hadist, disamping Imam Bukhari, Imam Muslim, dan Imam Nasa'i. Hadist tentang keutamaan makan sahur yang ia riwayatkan juga diriwayatkan oleh ketiga imam tersebut. Hal ini menandakan bahwasannya hadist tersebut adalah hadist yang diakui keshahihannya oleh para ulama hadist. 


\section{B. Teks Hadist Abu Dawud tentang Keutamaan Makan Sahur, Bab Shaum, no.} 1998.

Adapun hadist yang diriwayatkan oleh Abu Dawud yaitu:

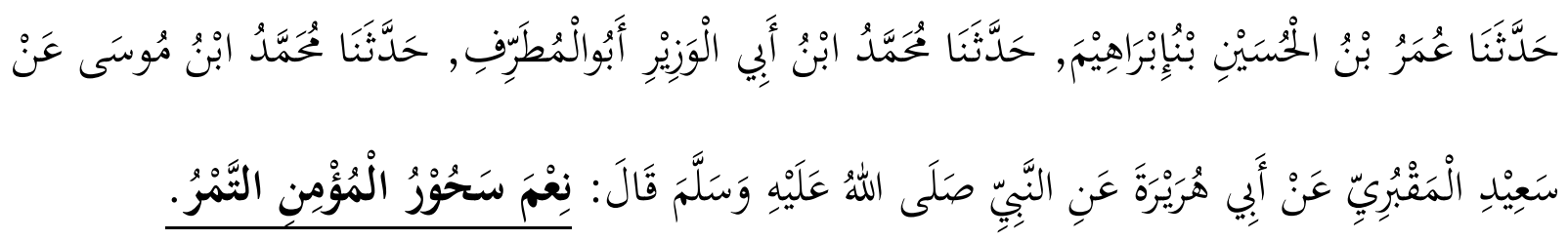

Secara tekstual dalam matan hadist yang diriwayatkan oleh Sunan Abu Daud tersebut dikatakan bahwa "sebaik-baiknya sahur bagi orang mukmin adalah dengan (tamar) kurma kering". Namun, jika dilihat secara kontekstual matan hadist tersebut menyimpan makna yang sangat mendalam, bisa jadi bukan hanya kurma saja yang baik untuk dimakan ketika sahur. Makna itulah yang nantinya akan dibahas dalam makalah ini.

\section{PEMBAHASAN}

\section{Kajian Linguistik}

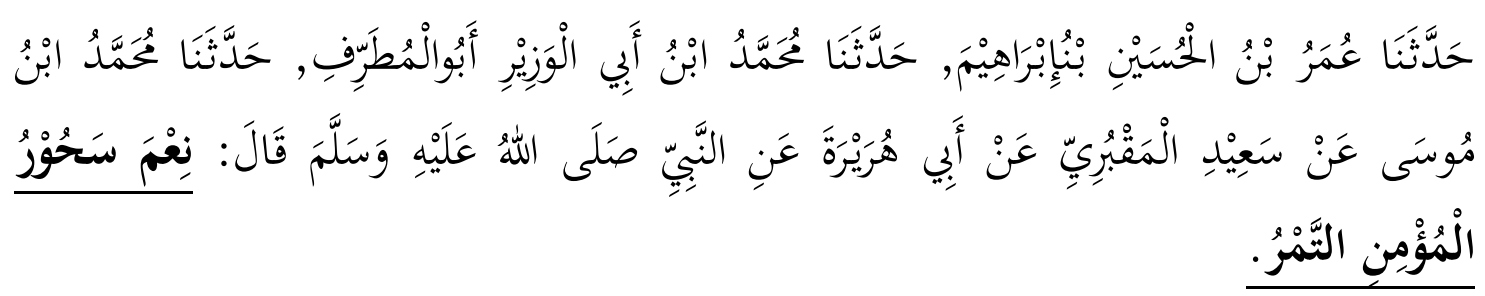




\section{Nurul Hidayah}

a. Makna ie

Lafadz sebagai mubalaghah terhadap pujian atau dengan kata lain yang utama. ${ }^{1}$

b. Makna سَحْوْز

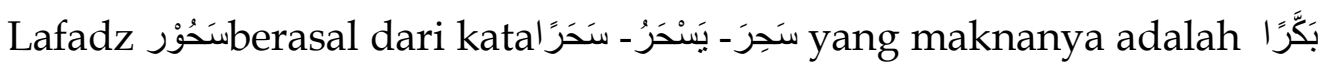
dalam bahasa indonesia diartikan pagi-pagi sekali. ${ }^{2}$ Sedang dalam kamus Munjid adalah akhir malam sebelum subuh. Adapun سَحُوْرsendiri maknanya adalah makan dan minum di akhir malam sebelum subuh. ${ }^{3}$ Dalam KBBI sahur adalah makan pada dini hari bagi orang yang menjalankan ibadah puasa. ${ }^{4}$

c. Makna الْمُوْْمِنِ

Lafadz الْهُوِْْنِdalam kamus KBBI memiliki makna orang yang beriman dan percaya kepada Allah. 5 Sedang dalam mu'jammaknanya adalah المُصَدِّق yang dalam bahasa indonesia diartikan orang yang mempercayai atau lawan dari kafir. ${ }^{6}$

\footnotetext{
${ }^{1}$ Lois Makluf, Al-Munjid fi al-Lunghah wal A'lam (Beirut: Maktabah Asy-Syarqiyyah, 1997), hlm. 820.
}

${ }^{2}$ Ahmad Warson Munawwir, Kamus al-Munawwir Arab-Indonesia Terlengkap, Cet. 14 (Yogyakarta: Pustaka Progessif, 1997), hlm. 101.

${ }^{3}$ Ibid., hlm. 323.

${ }^{4}$ Tim Penyusun Kamus Pusat Bahasa, Kamus Besar Bahasa Indonesia (Jakarta: Pusat Bahasa, 2008) hlm. 1243.

${ }^{5}$ Ibid, hlm. 979.

${ }^{6}$ Abi Mansur Muhammad Ibn Ahmad Al-Azhari, Mu'jam Tahdhib al-Lunghah (Beirut: Dar al-Ma'arif, 2001), hlm. 18.

\section{4 | Dinamika Vol. 1, No. 1, Desember 2016}




\section{Keutamaan Makan Sahur dengan Tamar (Kurma) (Kajian Kontekstual Hadist Abu Dawud)}

d. Makna التََّّْْ

Lafadz التَّْْر dalam kamus Al-Munawwir artinya adalah buah kurma.7 sedang dalam KBBI kurma adalah nama pohon palem yang buahnya dijadikan semacam manisan. ${ }^{8}$ Kurma secara umum merupakan nama buah dari pohon kurma sejak proses awal berbuah sampai matang. Kurma mentah disebut dengan busr, dan kurma matang yang tidak bertahan lamasetelah musim pembuahan disebut dengan ruthab. Sedang tamr adalah kurma kering yang dapat bertahan sepanjang tahun. ${ }^{9}$

Berdasarkan makna perkata yang telah dipaparkan di atas dapat dimaknai secara umum bahwa yang paling utama makanan orang mukmin ketika bersahur adalah kurma. Secara tersirat kurma tidak harus dipahami wujudnya buah kurma itu sendiri melainkan makanan yang manis-manis atau makanan bergizi yang dapat memberikan tenaga bagi orang yang berpuasa di siang harinya.

\section{Kajian Tematis Komprehensif}

Adapun hadist yang serupa dengan keutamaan makan sahur adalah sebagai berikut. ${ }^{10}$

\footnotetext{
${ }^{7}$ Ahmad Warson Munawwir, Kamus al-Munawwir Arab-Indonesia Terlengkap, hlm. 138.

${ }^{8}$ Tim Penyusun Kamus Pusat Bahasa, Kamus Besar Bahasa Indonesia, hlm. 782.

${ }^{9}$ Zaghlul An-Najjar, Sains Dalam Hadis: Mengungkap Fakta Ilmiah dari Kemukjizatan Hadis Nabi, Penerjemah: Zainal Abidin, dkk. (Jakarta: Amza, 2011), hlm. 236.

${ }^{10}$ Abu Dawud al-Sijistani, Sunan Abi Dawud, Edisi: Ke-3 (Lebanon: Dar Al-Kotob Al-Ilmiyah, 2007), 376-377.
} 


\section{Nurul Hidayah}

a. Bab mengokohkan sahur

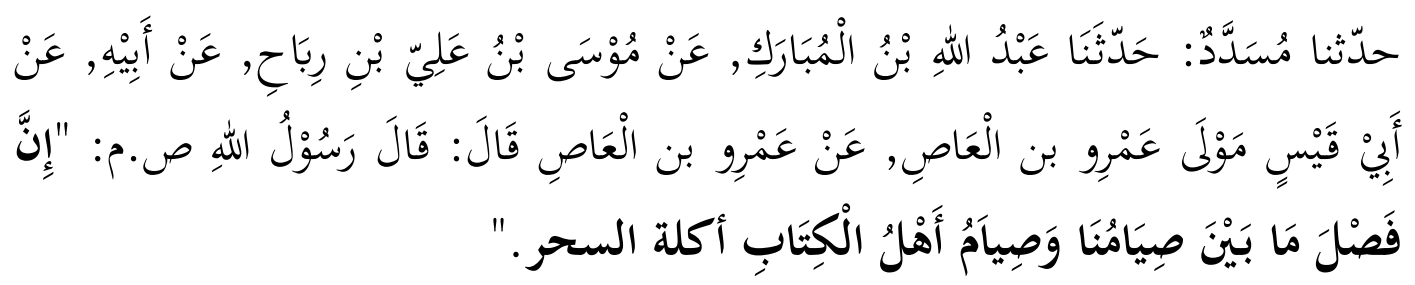

Hadist diatas menjelaskan tentang perbedaan puasa kita dengan orang ahli kitab terletak pada makan sahur. Dalam ajaran mereka tidak ada anjuran untuk makan sahur, sedang dalam ajaran kita Rosululloh menganjurkan makan sahur. Hadist tersebut dikeluarkan oleh Imam Muslim, Tirmidzi dan Nasa' ${ }^{11}$

b. Sahur disebut juga dengan sarapan

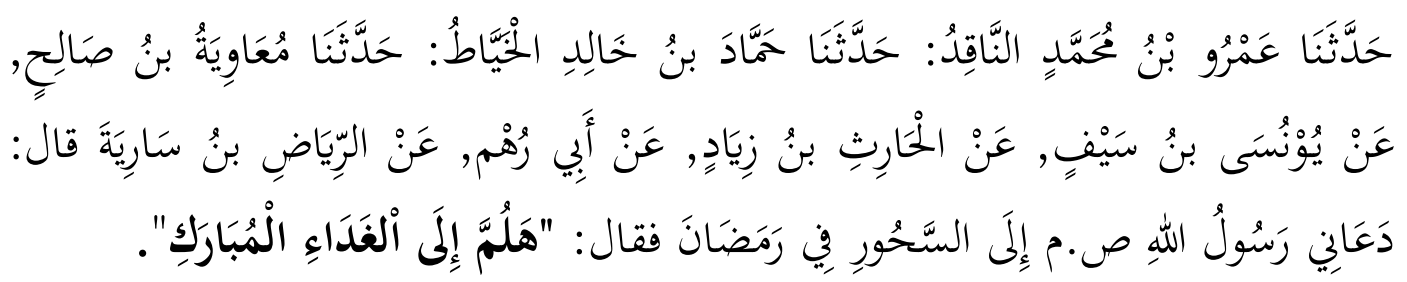

Dalam matan hadist di atas menjelaskan bahwasannya, yang dimaksud dengan ألََْدَاعِ(sarapan) adalah makan sahur. Sarapan pada bulan Ramadhan mengandung berkah di dalamnya. Hadist ini dikeluarkan oleh Nasa'i. ${ }^{12}$

${ }^{11}$ Abu Dawud, Terjemah Sunan Abi Dawud, Terjemah: Syamsul Arifin, dkk. (Semarang: CV. Asy-Syifa', 1992), hlm. 197.

${ }^{12} \mathrm{Ibid}$. Hlm198. 
c. Waktu sahur

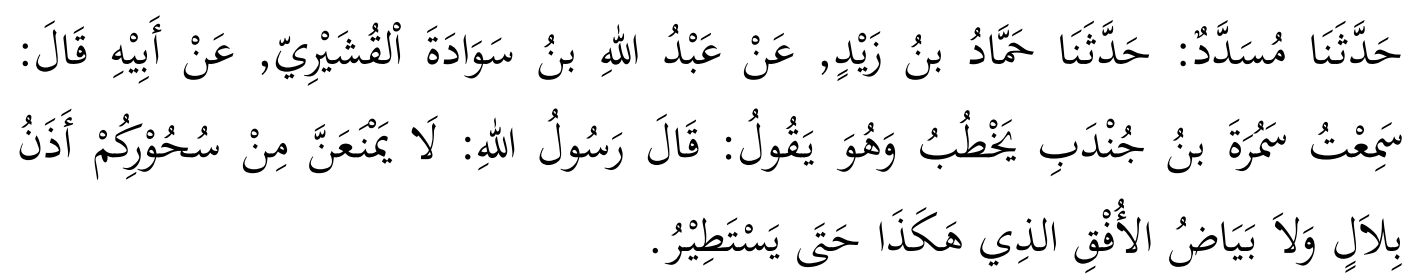

Hadist tersebut juga diriwayatkan oleh Muslim, Nasa'i dan AtTirmdzi. ${ }^{13}$ Dalam hadist tersebut dikatakan bahwaadzannya bilal bukanlah penghalang bagi orang yang melaksanakan sahur karena dia adzan pada malam hari dan jangan terpengaruh oleh panjangnya sinar putih di ufu' kecuali sinar putih itu telah memancar, hal ini telah menandakan terbitnya fajar. ${ }^{14}$

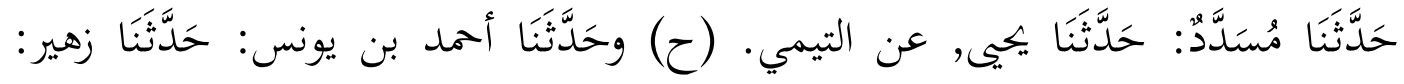

$$
\begin{aligned}
& \text { حَدَّثنًَا سليمان التيمي, عن أبي عثمان, عن عبد الله بن مسعود قال: قال رسول الله } \\
& \text { ص.م: لا يمتعن أحدكم أذان بلال من سحوره فإنه يؤذن" أو قال: "يناذي ليرجع قائمكم } \\
& \text { ويئتبه نائمكم" قال أحمد بن يونس في حديثه: "وليس الفجر أن يقول" يعني الفجر } \\
& \text { "هكذ". قال مسدد: وجمع يهيى كفه حتى يقول: هكذ, ومد يجيى بإصبعيه السبابتين. }
\end{aligned}
$$

Dalam hadist ini juga dijelaskan bahwa orang yang tengah melakukan makan sahur untuk tidak terpengaruh dengan adzan yang dikumandangkan oleh Bilal, karena adzan yang ia kumandangkan seruan

${ }^{13}$ Muhammad Syamsul Haqq Al-'Azim Abadi; ibn Qayyim al-Jauziyyah, Awn Al-Ma'bud: Syarah Sunan Abi Dawud (Beirut: Dar al-Kutub al-Ilmiyyah, 2009), hlm. 31.

${ }^{14}$ Muhammad Nasib ar-Rifa'i, Kemudahan dari Allah: Ringkasan Tafsir Ibn Katsir (Jakarta: Gema Insani Press, 1999), hlm. 232. 


\section{Nurul Hidayah}

untuk tahajjud. Sedang waktu fajar yang dijelaskan dalam hadist ini sama halnya dengan yang dijelaskan pada hadist sebelumnya. Hadist ini dikeluarkan oleh Bukhari, Muslim, Nasa'i, dan Ibn Majah. ${ }^{15}$

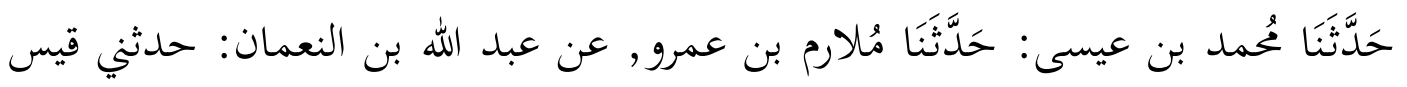

$$
\begin{aligned}
& \text { بن طلق, عن أبيه قال: قال رسول الله ص.م: كلوا واشربوا حتي يعترض لكم الأحمر. }
\end{aligned}
$$

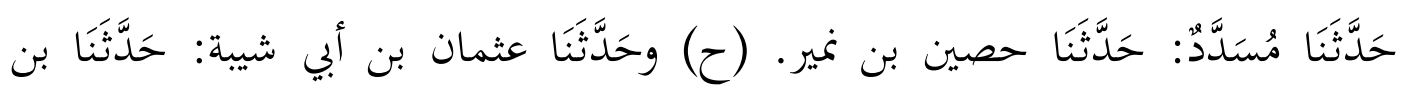

$$
\begin{aligned}
& \text { إدريس, المعنى من حصين, عن الشعبي, عن عدي بن خاتح, قال: "لما نزلت هذه الآية: }
\end{aligned}
$$

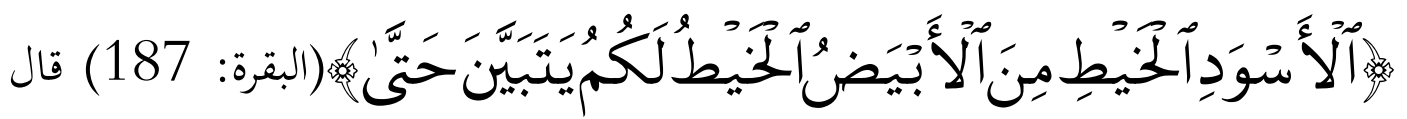

$$
\begin{aligned}
& \text { أخذت عقالا أبيض وعقالا أسود, فوضعتهما تحت وسادتي, فنظرت فلم أتبن, فذكرت } \\
& \text { ذلك لرسولله ص.م. فضحكك فقال: "إن وسادك إذا لعريض طويل إنما هو الليل والنهار". } \\
& \text { وقال عثمان: إنما هو سواد الليل وبياض النهار". }
\end{aligned}
$$

Dalam hadist tersebut dijelaskan bahwa yang dimaksud dengan benang putih dan benang merah bukan lah arti benang yang sesungguhnya akan tetapi

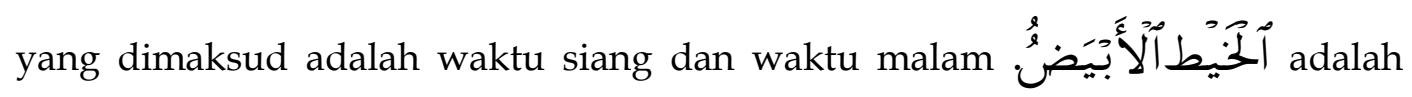

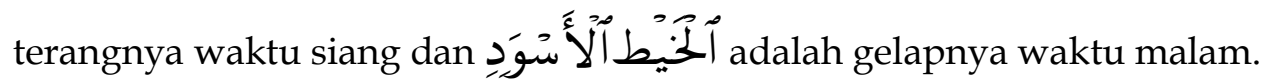

\footnotetext{
${ }^{15}$ Abi Dawud, Terjemah Sunan Abi Dawud, hlm. 199.
} 
d. Sedang makan sahur kemudian mendengar adzan subuh

$$
\begin{aligned}
& \text { حَدَّنَنَا عبد الأعلى بن حماد: حَدَّتَنَا حماد, عن عُمَّمَ بن عمرو, عن أبي سلمة, عن أبى } \\
& \text { هريرة قال: قال رسول الله ص.م.: إذا سمع أحدكم النداء والإناء على يده فلا يضعه حتى } \\
& \text { يقضى حاجته منه. }
\end{aligned}
$$

Dalam hadist diatas dapat dipahami bahwasannya, jika seseorang sedang makan sahur kemudian mendengar adzan subuh maka hendaknya dia menghabiskan apa yang ada ditangannya.

Pada hadist-hadist yang telah disebutkan di atas menunjukkan bahwa Rosullullah sangat menganjurkan pentingnya sahur. Hal itu bukan hanya sekedar agar tidak lapar disiang harinya namun, di dalam sahur tersebut mengandung berkah dan agar orang mukmin dapat menjalankan tahajjud. Selain itu, hadist di atas juga menjelaskan tentang waktu bersahur.

\section{Kajian Konfirmatif}

a) Ayat tentang Sahur (Al-Baqoroh: 187)

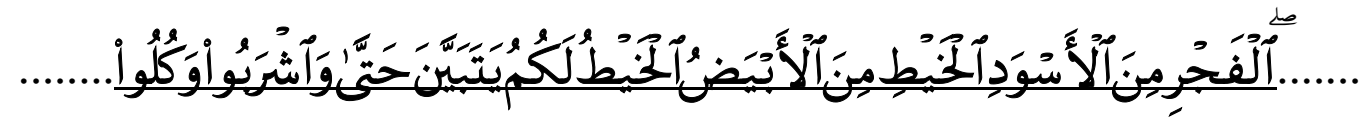

"....Makan minumlah hingga terang bagimu benang putih dari benang hitam, Yaitu fajar. kemudian sempurnakanlah puasa itu sampai (datang) $\underline{\text { malam }_{1} . . .}$

Pada lafadz yang digaris bawah dalam ayat di atas dapat dipahami bahwa Allah memberikan kemurahan terhadap umat-Nya sebagai tanda rahmat dan 


\section{Nurul Hidayah}

kasing sayang. Allah memperbolehkan makan dan minum sampai jelasnya pagi dan malam. Hal ini adalah dalil disunnahkannya sahur bagi orang yang hendak menjalankan puasa esok harinya. ${ }^{16}$ Jadi, sahur bukan semata-semata hanya untuk mencegah rasa lapar ketika siang harinya akan tetapi juga mengandung keberkahan di dalamnya.

b) Ayat tentang Kurma

1) Q.S. Al-Rahman: 11:

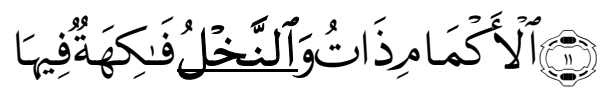

"Di bumi itu ada buah-buahan dan pohon kurma yang mempunyai kelopak mayang." (Q.S. Maryam: 11).

2) Q.S. Maryam: 25-26.

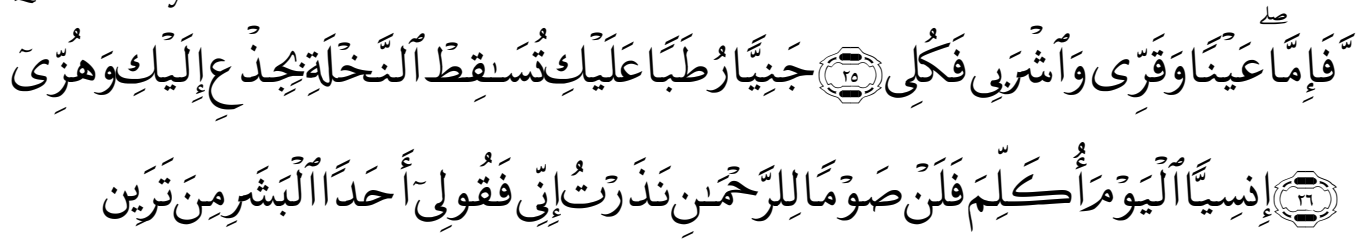

"Dan goyanglah pangkal pohon kurma itu ke arahmu, niscaya pohon itu akan menggugurkan buah kurma yang masak kepadamu, Maka makan, minum dan bersenang hatilah kamu. jika kamu melihat seorang manusia, Maka Katakanlah: "Sesungguhnya aku telah bernazar berpuasa untuk Tuhan yang Maha pemurah, Maka aku tidak akan berbicara dengan seorang manusiapun pada hari ini". (QS. Maryam: 25-26).

\section{Analisis Realitas Historis}

Dalam memahami sebuah matan hadist tidak cukup hanya sebatas memahami secara tekstual saja. Melainkan, harus melihat konteks yang melingkupinya. Dengan kata lain, ketika kita menggali pesan moral yang

\footnotetext{
${ }^{16}$ Muhammad Nasib ar-Rifa'i, Kemudahan dari Allah: Ringkasan Tafsir Ibn Katsir, hlm. 231.
} 


\section{Keutamaan Makan Sahur dengan Tamar (Kurma) (Kajian Kontekstual Hadist Abu Dawud)}

terkandung dalam matan hadist, kita perlu melihat konteks historis, kepada siapa hadist tersebut disampaikan, serta dalam kondisi sosio-kultural apa hadist tersebut disampaikan Nabi. Tanpa adanya penggalian secara historis, seseorang akan mengalami kesulitan dalam memahami makna hadist. Bahkan bisa jadi akan menangkap pemahaman yang kurang tepat. ${ }^{17}$

Dalam hadist yang diriwayatkan oleh Abu Sawud dan Al-Tirmidzi dari Anas r.a dikatakan bahwa "Rasulullah selalu berbuka puasa dengan kurma matang sebelum melaksanakan salat. Jika tidak ada kurma matang maka dengan kurma muda, dan jika tidak ada kurma muda maka Nabi berbuka dengan beberapa teguk air putih."18 Rasulullah tidak hanya menganjurkan berbuka puasa akan tetapi juga menganjurkan untuk bersahur seperti yang terdapat dalam hadist"Sahur adalah makanan berkah, maka jangan kalian tinggalkan walaupun hanya meneguk seteguk air, karena Allah dan para malaikat bershalawat atas orang-orang yang bersahur" (HR Ibnu Syaibah dan Ahmad).Hal terpenting dari makan sahur bukan terletak dari sedikit banyaknya makanan yang dikonsumsi. Dalam aktivitas sahur terdapat keberkahan dan pertolongan Allah Swt. Seperti yang terdapat dalam hadist" 19

17 Said Agil Husin Munawwar dan Abdul Mustaqim, Asbabul Wurud Studi Kritis Hadist Nabi: Pendekatan Sosio-Historis-Kontekstual (Yogyakarta: Pustaka Pelajar, 2001), hlm. 6.

${ }^{18}$ Diriwayatkan oleh Abu Dawud dalam bab As-Shaum (2356), At-Tirmidzi dalam bab As-Shaum (696), imam Ahmad dalam bab As-Shaum (1226). Dikutip dari Ensiklopedia Mukjizat Alquran dan Hadist: Penciptaan Hewan dan tumbuhan. Hlm. 70.

${ }^{19} \mathrm{http}: / /$ syaamilquran.com/keutamaan-makan-sahur-di-bulan-ramadhan.html. Diakses pada: Senin, 14 April 2014, Pukul: !7.02. 


\section{Nurul Hidayah}

Berdasarkan pemahaman penulis mengenai realitas historis yang terdapat dalam hadist Abu Dawud tentang keutamaan sahur dengan tamar, bahwasannya dalam bersahur terdapat berkah, yang dimaksud dengan berkah disini adalah ketika seseorang makan atau minum akan mendapatkan kekuatan dalam menjalankan puasa di siang harinya. Dengan catatan tidak berlebihan, karena jika makan atau minum secara berlebihan justru sisa makanan di dalam lambung akan terbuang banyak dan seseorang akan merasa cepat lapar. ${ }^{20}$ Selain itu, Allah dan para malaikat akan bersholawat kepada orang-orang yang bersahur..$^{21}$

Adapun anjuran makan sahur dengan tamar (kurma kering) tak lain karena kandungan gula dan gizi yang ada di dalamnya sangat baik untuk menambah energi di siang harinya. Ibnu Qoyyim al-Jauziyah mengatakan bahwa kurma mengandung gizi yang mengenyangkan dan dibutuhkan tubuh karena kandungan unsur panas dan lembab. Bila dikunyah dan ditelan, bisa pula membunuh cacing. Selain panas, buah ini juga memiliki energi tambahan. Kurma adalah buah, makanan, obat, minuman, sekaligus gula-gula yang bermanfaat bagi jantung dan tubuh untuk dijadikan sebagai sumber energi..22 Dengan alasan itulah, Rasulullah menganjurkan untuk sahur menggunakan

${ }^{20}$ Hisham Thalbah, Ensiklopedia Mukjizat Alquran dan Hadist: Kemukjizatan Tumbuhan dan Buahbuahan, hlm. 60 .

${ }^{21}$ http://www.rumahislam.com/ibadah/289-puasa/1304-sahur.html?start=1. Diakses pada: Senin, 14 April 2014, Pukul: !7.00.

${ }^{22}$ Hisham Thalbah, Ensiklopedia Mukjizat Alquran dan Hadist: Kemukjizatan Tumbuhan dan Buahbuahan, hlm. 32 . 
tamar (kurma kering). Disamping itu, kurma juga merupakan buah yang sangat diagungkan oleh Allah di dalam Alquran. Hal ini terbukti dari penyebutan kata al-nahl di dalam Alquran.

Pohon kurma juga merupakan salah satu pohon yang berusia panjang dan hijau. Pada dasarnya pohon kurma hanya dapat tumbuh di kawasan panas, namun juga dapat beradaptasi dengan kawasan yang beriklim sedang dan kering. Pohon kurma juga merupakan pohon yang memiliki peluang terbanyak untuk hidup dan tertanam di kawasan beriklim kering dan asin. Oleh karenanya pohon kurma mudah ditanam meski di kawasan yang tandus sekalipun. Sejak zaman dahulu, hasil pohon kurma dianggap sebagai salah satu sumber penting buah-buahan yang menjadi topangan dan sandaran hidup manusia, terutama di kawasan gurun. ${ }^{23}$

Kurma juga merupakan khas orang Arab, baik yang berada di perkotaan maupun yang di pedesaan. Mereka selalu mengidentikkan kurma dengan ketenangan, ketentraman, dan kesabaran. Dengan demikian, kurma dapat dijadikan sebagai penawar bagi orang yang sedang didera kegamangan. ${ }^{24}$ Itulah sekiranya alasan yang dapat dijadikan sebagai realitas historis atas anjuran Rasulullah untuk mengkonsumsi kurma baik mentah maupun matang.

${ }^{23}$ Zaghlul An-Najjar, Sains Dalam Hadis: Mengungkap Fakta Ilmiah dari Kemukjizatan Hadis Nabi, hlm. 236.

${ }^{24}$ Ibid., 32-33. 


\section{Nurul Hidayah}

\section{Analisis Generalisasi}

Dari penjelasan di atas dapat digeneralisasikan bahwa sabda Rasulullah mengenai sebaik-baiknya sahur bagi orang mukmin adalah dengan makan kurma sangat erat hubungannya dengan kesehatan manusia. Selain mengandung keberkahan di dalam menjalankan sahur namun juga mendapatkan manfaat yang sangat besar dari buah kurma ketika dikonsumsi. Sebagian diantara kita mungkin masih mengira bahwa kurma baik dikonsumsi ketika berbuka puasa saja. Tapi berdasarkan hadist Nabi kurma juga baik dikonsumsi ketika sahur.

Manfaat kurma ketika dikonsumsi pada saat sahur dapat mencegah lapar. Orang yang berpuasa sangat membutuhkan zat gula yang ada dalam tubuhnya, terlebih yang tersimpan dalam liver. Zat gula yang terdapat pada sahur orang yang berpuasa hanya mampu mencukupi zat gula tubuh selama enam jam saja, setelah itu mulailah meminta bantuan zat gula yang terdapat pada liver. ${ }^{25}$

Oleh karena itu, orang yang berpuasa dan berbuka dengan kurma, zat besi yang tunggal akan sampai ke darah dan liver dengan cepat, dan kemudian disalurkan keseluruh anggota tubuh terutama ke bagian otak. ${ }^{26}$ Adapun hadist yang menguatkan bahwa kurma merupakan makanan yang dapat mencegah lapar yaitu hadist dari Aisyah radhiyallahu 'anha, dia

${ }^{25}$ Zaqlul an-Najjar dan Abdul Daim Kalil,Ensiklopedia Mukjizat Alquran dan Hadist: Penciptaan Hewan dan tumbuhan (Jakarta: Lentera Abadi, 2012), hlm. 78.

${ }^{26} \mathrm{Ibid}$. 


\section{Keutamaan Makan Sahur dengan Tamar (Kurma) (Kajian Kontekstual Hadist Abu Dawud)}

berkata bahwa Rasulullah shallallahu 'alaihi wa sallam pernah bersabda:"Rumah yang tidak ada tamr (kurma kering) di dalamnya, akan menjadikan lapar penghuninya." [HR. Muslim (no. 2046 (153), at-Tirmidzi (no. 1815), Abu Dawud (no. 3831) dan Ibnu Majah (no. 3327)]. Hadits tersebut merupakan dalil mengenai keutamaan tamr (kurma kering) dan diperbolehkannya untuk menyimpannya sebagai perbekalan makanan."27

Jika kita pahami lebih dalam pesan yang terkadung dalam hadist tersebut bersifat tasyari'iyah dan ghairu tasyar'iyah. Anjuran sahur yang diperintahkan oleh Rosululloh merupakan perintah yang bersifat tasyri'iyah. Dalam hal ini sahur sangat dianjurkan bagi orang mukmin yang hendak menjalankan ibadah puasa di siang harinya agar puasa yang ia jalankan tidak menimbulkan penyakit di kemudian hari. Anjuran tersebut bersifat universal, bagi umat islam yang hendak menjalankan ibadah puasa dan tidak terbatas wilayah, usia, maupun kelompok sosial.

Sementara anjuran sahur menggunakan kurma merupakan perintah ghairu tasyri'iyah yang bersifat lokal temporal. Hal ini dengan alasan bahwa buah kurma merupakan makanan khas orang arab, bukan makanan yang dapat dengan mudah ditemui di negara-negara lainnya kecuali musim-musim tertentu. Kurma hanya terbatas pada wilayah jazirah arab saja. Jadi, jika buah

${ }^{27}$ Syarh Shahih Muslim (XIII/230) oleh Imam an-Nawawi, cet. Daar Ibnu Haitsam, th. 2003 M. Melalui http://duiseribusatumalam.blogspot.com/2011/08/kurma-adalah-sebaik-baik-makanan-untuk.html. Diakses pada: Senin, 14 April 2014, Pukul: 17.00. 


\section{Nurul Hidayah}

kurma bukan merupakan satu-satunya makanan yang terbaik ketika sahur. Akan tetapi, kita dapat menggantinya dengan makanan yang bergizi yang dapat menambah energi ketika menjalankan puasa di esok hari. Seperti contoh di Indonesia, kita dapat mengganti kurma dengan makan nasi, sayur-sayuran, lauk-pauk, makanan atau minuman yang manis-manis.

\section{Kritik Praksis}

Pada bagian kritik praktis ini, kajian pemahaman hadist difokuskan pada kajian pemahaman dihubungkan dengan permasalahan yang ada masa kini. Ketika bulan ramadhan tiba sering kali kita menjumpai orang-orang yang ada disekeliling kita pada waktu sahur dimanfaatkan untuk makan sebanyakbanyaknya. Hal itu, justru akan menyebabkan seseorang menjadi cepat lapar dan tenaga yang disimpan menjadi berkurangkarena sisa makanan banyak yang terbuang. Dengan makan dan minum secukupnya sesuatu yang manis ketika sahur akan menjadikan seseorang tidak mudah lapar dan mempunyai energi saat menjalankan puasa disiang harinya.

Rasululloh menganjurkan untuk sahur dan berbuka dengan kurma atau sesuatu yang manis. Karena makanan yang manis dapat menambah energi pada tubuh seseorang. Hal ini, merupakan keringanan jika tidak ada kurma. Berkaitan dengan makan sahur, jika diterapkan pada masyarakat sekarang sangat tidak bertentangan baik dari segi agama maupun realitas 


\section{Keutamaan Makan Sahur dengan Tamar (Kurma) (Kajian Kontekstual Hadist Abu Dawud)}

sosial. Seperti kita ketahui bersama bahwasannya kehidupan masyarakat di Indonesia telah mengalami banyak kemajuan, khususnya dalam bidang pendidikan dan pekerjaan.

Dalam bidang pendidikan, setiap warga Indonesia wajib merasakan bangku sekolah minimal enam tahun. Dalam hal ini, pada bulan ramadhan kegiatan belajar mengajar tetap berjalan sebagai mana mestinya meskipun ada pengurangan pada jam pelajaran. Bagi pelajar khususnya pada usia sekolah dasar bukanlah hal yang mudah untuk menjalankan puasa di tengah-tengah kegiatan di sekolah yang cukup menguras energi. Untuk mengurangi rasa letih ketika menjalankan aktivitas di sekolah, akan sangat baik jika anak-anak makan sahur ketika malam hari. Dengan demikian, mereka tetap dapat beraktivitas sesuka hati meskipun dalam kondisi berpuasa.

Hal di atas juga dapat diterapkan bagi semua kalangan, baik anakanak, remaja maupun orang dewasa, baik pelajar maupun pekerja kantoran ataupun lapangan. Karena perintah sahur merupakan perintah yang bersifat umum, tidak terbatas wilayah, usia, maupun golongan. Jadi, dalam bersahur selain bentuk kataqwaan kita terhadap Allah dan mengikuti sunnah Rasulullah juga dapat membantu menambah energi saat berpuasa dalam menjalankan aktivitas sehari-sehari. Dengan bersahur seseorang dapat menyimpan kebutuhan energi selama berpuasa sehingga tetap bersemangat menjalankan aktivitas. Puasa bukan halangan untuk menjalan kegiatan, 


\section{Nurul Hidayah}

belajar, ataupun bekerja. Berbeda dengan orang yang tidak makan sahur ketika hendak berpuasa, tenaga yang disimpan tidak sebanyak orang yang sahur, dan akan cepat letih.

Adapun makanan yang dikonsumsi saat sahur, tidak harus kurma meskipun kurma adalah sebaik-baiknya makanan ketika sahur. Perintah yang terkandung dalam hadist tersebut bukanlah tasyri'iyah yang bersifat universal yang harus dijalankan bagi semua orang. Melainkan perintah yang ghairu tasyri'yah yang bersifat lokal temporal, anjuran bagi wilayah tertentu yang banyak tumbuh pohon kurma. Dengan kata lain, kurma dapat diganti dengan makanan tertentu yang terdapat di masing-masing wilayah. Karena tidak semua wilayah terdapat pohon kurma. Kurma hanyalah simbol yang digunakan untuk makanan bergizi yang kaya akan manfaat atau simbol dari makanan pokok wilayah tertentu.

Pada konteks wilayah Indonesia yang kaya akan hasil bumi, kurma dapat diganti dengan makanan pokok Indonesia, seperti nasi, gandum, tebu, kopi, sayur, buah-buhan dan lain sebagainya. Atau dengan kata lain, empat sehat lima sempurna, yang di dalamnya terdapat nasi, sayur, lauk, buahbuahan dan susu. Jika di Jazirah Arab kurma merupakan makanan yang dijadikan sebagai sumber gizi dan energi, maka hal tersebut di ataslah yang dijadikan masyarakat Indonesia sebagai sumber gizi dan energi. 


\section{Kesimpulan}

Dari beberapa langkah yang ditempuh dapat ditarik kesimpulan bahwa sahur bukan hanya sekedar makan dan minum untuk mencegah lapar pada siang harinya. Akan tetapi juga anjuran dari Rosulullah yang di dalanya mengandung berkah dan pertolongan dari Allah. Karena pada saat sahur itulah Allah dan para malaikat bershalawat kepada orang-orang yang melaksanakan sahur, meskipun hanya dengan seteguk air. Rasulullah menganjurkan umatnya untuk bersahur dengan makan kurma atau makanan yang manis-manis bergizi yang dapat menjadi energi ketika menjalankan ibadah puasa.

Segala sesuatu yang dianjurkan Nabi selalu terdapat kandungan manfaat yang sangat kaya dalam segala bidang kehidupan. Dengan cara makan sahur menggunakan kurma atau makanan yang bergizi bukan hanya sekedar menjalankan sunnah Rosul melainkan juga mendapatkan banyak manfaat dari makanan yang kita makan. Kurma ataupun makanan pokok lain adalah tambang mineral, mungkin itulah kata yang sesuai untuk menggambarkan segala manfaat kurma dan makanan lain yang tumbuh dari bumi. 


\section{Nurul Hidayah}

\section{DAFTAR PUSTAKA}

Abi Mansur Muhammad Ibn Ahmad Al-Azhari, Mu'jam Tahdhib al-Lunghah, Beirut: Dar al-Ma'arif, 2001.

Abu Dawud al-Sijistani, Sunan Abi Dawud, Edisi: Ke-3, Lebanon: Dar Al-Kotob AlIlmiyah, 2007. Terjemah Sunan Abi Dawud, Penerjemah: Syamsul Arifin, dkk., Semarang: CV. Asy-Syifa', 1992.

An-Najjar,Zaqlul dan Abdul Daim Kalil,Ensiklopedia Mukjizat Alquran dan Hadist: Penciptaan Hewan dan tumbuhan, Jakarta: Lentera Abadi, 2012.

Sains Dalam Hadis: Mengungkap Fakta Ilmiah dari Kemukjizatan Hadis Nabi, Penerjemah: Zainal Abidin, dkk., Jakarta: Amza, 2011.

Ahmad Warson Munawwir, Kamus al-Munawwir Arab-Indonesia Terlengkap, Cet. 14, Yogyakarta: Pustaka Progessif, 1997.

Lois Makluf, Al-Munjid fi al-Lunghah wal A'lam, Beirut: Maktabah Asy-Syarqiyyah, 1997.

Muhammad Nasib ar-Rifa'i, Kemudahan dari Allah: Ringkasan Tafsir Ibn Katsir, Jakarta: Gema Insani Press, 1999.

Muhammad Syamsul Haqq Al-'Azim Abadi; ibn Qayyim al-Jauziyyah, Awn AlMa'bud: Syarah Sunan Abi Dawud, Beirut: Dar al-Kutub al-Ilmiyyah, 2009.

Said Agil Husin Munawwar dan Abdul Mustaqim, Asbabul Wurud Studi Kritis Hadist Nabi: Pendekatan Sosio-Historis-Kontekstual, Yogyakarta: Pustaka Pelajar, 2001.

Tim Penyusun Kamus Pusat Bahasa, Kamus Besar Bahasa Indonesia, Jakarta: Pusat Bahasa, 2008.

http:// duiseribusatumalam.blogspot.com/2011/08/kurma-adalah-sebaik-baikmakanan-untuk.html.

http://syaamilquran.com/ keutamaan-makan-sahur-di-bulan-ramadhan.html. http:// www.rumahislam.com/ibadah/289-puasa/1304-sahur.html?start=1 